\title{
Erratum to: Novel Hybrid Ligands for Passivating PbS Colloidal Quantum Dots to Enhance the Performance of Solar Cells
}

\author{
Yuehua Yang $^{1} \cdot$ Baofeng Zhao $^{1} \cdot$ Yuping Gao $^{1} \cdot$ Han Liu $^{1} \cdot$ Yiyao Tian $^{1} \cdot$ Donghuan Qin $^{1} \cdot$ Hongbin Wu $^{1} \cdot$ \\ Wenbo Huang ${ }^{1} \cdot$ Lintao Hou $^{2}$
}

Published online: 16 January 2016

(C) The Author(s) 2016. This article is published with open access at Springerlink.com

Erratum to: Nano-Micro Lett. (2015) 7(4):325-331

DOI 10.1007/s40820-015-0046-4

In the original publication, the accepted date was published incorrectly. The correct accepted date should read as follows: "Accepted: 30 May 2015"

Open Access This article is distributed under the terms of the Creative Commons Attribution 4.0 International License (http:// creativecommons.org/licenses/by/4.0/), which permits unrestricted use, distribution, and reproduction in any medium, provided you give appropriate credit to the original author(s) and the source, provide a link to the Creative Commons license, and indicate if changes were made.

The online version of the original article can be found under doi:10.1007/s40820-015-0046-4.

Donghuan Qin

qindh@scut.edu.cn

1 State Key Laboratory of Luminescent Materials \& Devices, Institute of Polymer Optoelectronic Materials \& Devices, South China University of Technology, Guangzhou 510640, People's Republic of China

2 Siyuan Laboratory, Department of Physics, Jinan University, Guangzhou 510632, People's Republic of China 